\title{
Observations of Wood Bison Swimming across the Liard River, Northwest Territories, Canada
}

\author{
N.C. LARTER,,${ }^{1,2}$ J.S. NISHI, ${ }^{3}$ T. ELLSWORTH,${ }^{3}$ D. JOHNSON,${ }^{3}$ G. MORE ${ }^{4}$ and D.G. ALLAIRE ${ }^{1}$
}

(Received 31 January 2003; accepted in revised form 23 May 2003)

\begin{abstract}
We observed a group of 18 wood bison, of mixed sex and age classes, swimming across a $1.7 \mathrm{~km}$ wide section of the Liard River on 16 July 2002. Water levels and flow rates were above the long-term average for that time of year, and there was a river current of $14-16 \mathrm{~km} / \mathrm{h}$. The animals took at least 27 minutes to negotiate their $3.6 \mathrm{~km} \mathrm{swim}$. Younger animals were able to keep more of their head and body above the water level than older mature males. Calves of the year, observed swimming across a secondary channel of the river on 15 July 2003, had only their heads above water. Bison are capable of swimming across lakes and rivers (Wood Buffalo National Park, Yellowstone National Park), but well-documented cases of bison navigating rapidly flowing northern rivers are rare. Open-water crossings of the Liard River are important to the ecology of the Nahanni wood bison population, especially since seismic activity in the Liard River Valley is likely to increase.
\end{abstract}

Key Words: Liard River, wood bison, Bison bison athabascae, swimming

RÉSUMÉ. Le 16 juillet 2002, on a observé un groupe de 18 bisons des bois, des deux sexes et de groupes d'âge divers, traversant à la nage une section de la rivière Liard large de $1,7 \mathrm{~km}$. Le niveau d'eau et le débit fluvial dépassaient la moyenne à long terme pour cette période de l'année, et le courant fluvial y était de 14 à $16 \mathrm{~km} / \mathrm{h}$. Les animaux ont mis au moins 27 minutes pour négocier leur traversée de 3,6 km. Les plus jeunes pouvaient garder hors de l'eau une plus grande partie de leur tête et de leur corps que d'autres mâles plus âgés. Les veaux de l'année, que l'on a observés le 15 juillet 2003, durant leur traversée à la nage d'une branche secondaire de la rivière, n'avaient que la tête hors de l'eau. Les bisons sont capables de traverser des lacs et des rivières (parc national Wood Buffalo, parc national Yellowstone), mais on ne connait que peu de cas bien documentés de bisons négociant la traversée de cours d'eau nordiques à courant rapide. La traversée des eaux libres de la Liard est importante pour l'écologie de la population du bison des bois de la Nahanni, en particulier si l'on considère que la prospection sismique va probablement augmenter dans la vallée de la Liard.

Mots clés: rivière Liard, bison des bois, Bison bison athabascae, traversée à la nage

Traduit pour la revue Arctic par Nésida Loyer.

\section{INTRODUCTION}

The Nahanni wood bison (Bison bison athabascae) population was established in 1980, when 28 bison from Elk Island National Park (EINP) were released into an area near Nahanni Butte in the southwestern Northwest Territories (Gates et al., 2001; Fig. 1). The introduced founder population fragmented, and by fall 1980, wood bison were found near Fort Nelson, British Columbia, $250 \mathrm{~km}$ south of the initial release site. By 1981, bison numbers had declined to 14 individuals through accidental deaths and dispersal. By 1989, bison numbers had increased to ca. 40 individuals, and a supplemental release of 12 wood bison was undertaken in March 1989. During an aerial survey in 1992, 55 bison were observed: one group of 18 was found near Nahanni Butte and the remaining 37 occurred along the Liard River valley as far south as La Jolie Butte in northeastern British Columbia. Aerial surveys in 1995, 1996, and 1997 resulted in counts of 64, 78, and 107 bison, respectively (Gates et al., 2001; GNWT, unpubl. data). In March 1998, a second supplemental release of 61 wood bison from EINP was undertaken. Although the plan was to hold the bison in a fenced enclosure near the Muskeg River for up to 25 days to habituate them to the area, the animals escaped prematurely from the enclosure, and a group of 17 bison dispersed southward into the Fort Nelson area.

\footnotetext{
${ }^{1}$ Government of the Northwest Territories, Department of Resources, Wildlife \& Economic Development, P.O. Box 240, Fort Simpson, Northwest Territories X0E 0N0, Canada

${ }^{2}$ Corresponding author: Nic_Larter@gov.nt.ca

${ }^{3}$ Government of the Northwest Territories, Department of Resources, Wildlife \& Economic Development, P.O. Box 390, Fort Smith, Northwest Territories X0E 0P0, Canada

${ }^{4}$ Government of the Northwest Territories, Department of Resources, Wildlife \& Economic Development, General Delivery, Fort Liard, Northwest Territories X0G 0A0, Canada; present address: Government of the Northwest Territories, Department of Resources, Wildlife \& Economic Development, 600, 5102-50th Avenue, Yellowknife, Northwest Territories X1A 3S8, Canada

(C) The Arctic Institute of North America
} 


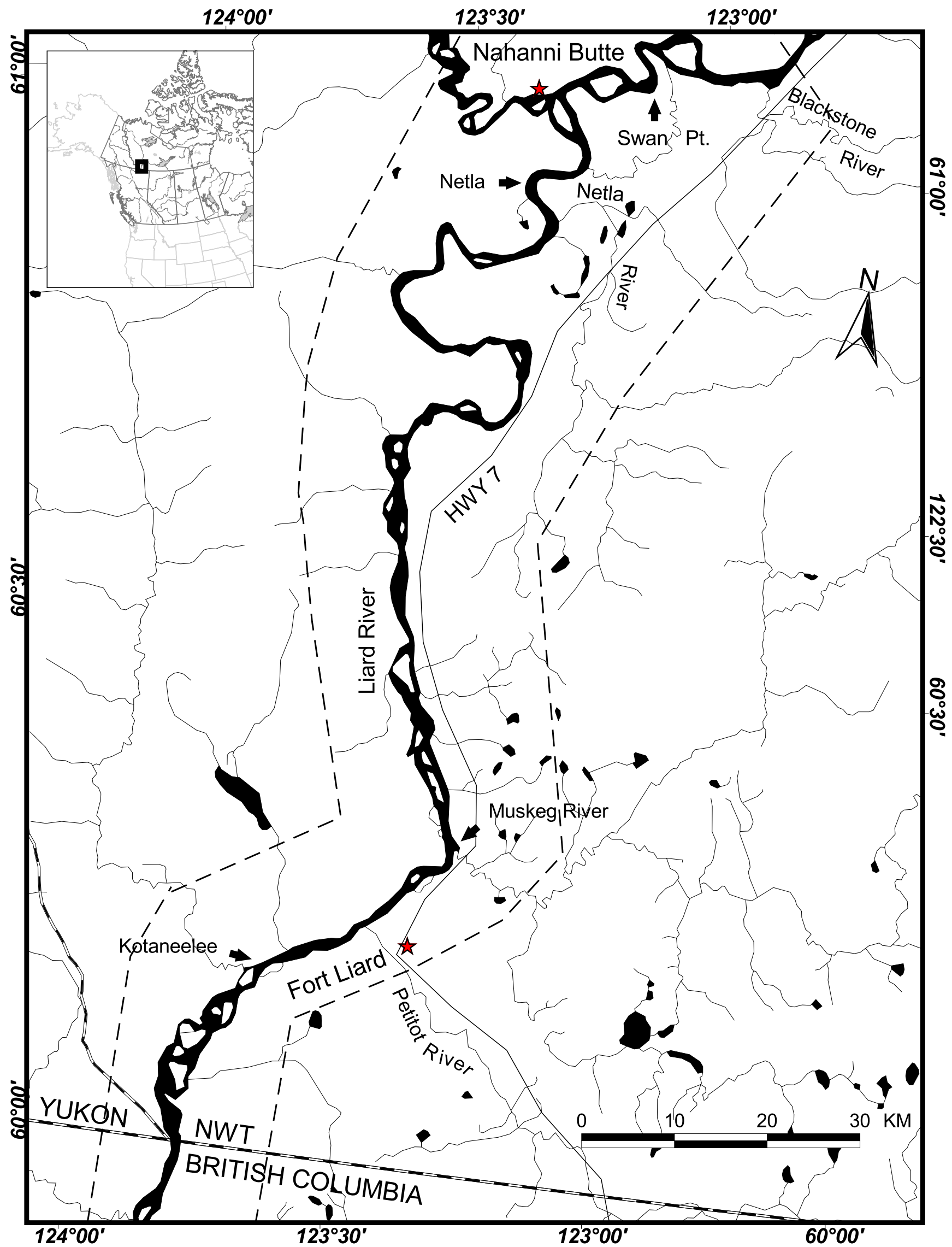

FIG 1. The southwestern Northwest Territories. The area between the dashed lines indicates the range of the Nahanni bison population between $60^{\circ}$ and $61^{\circ} \mathrm{N}$ latitude. The arrows indicate the four general areas where bison are known to cross the Liard River. 


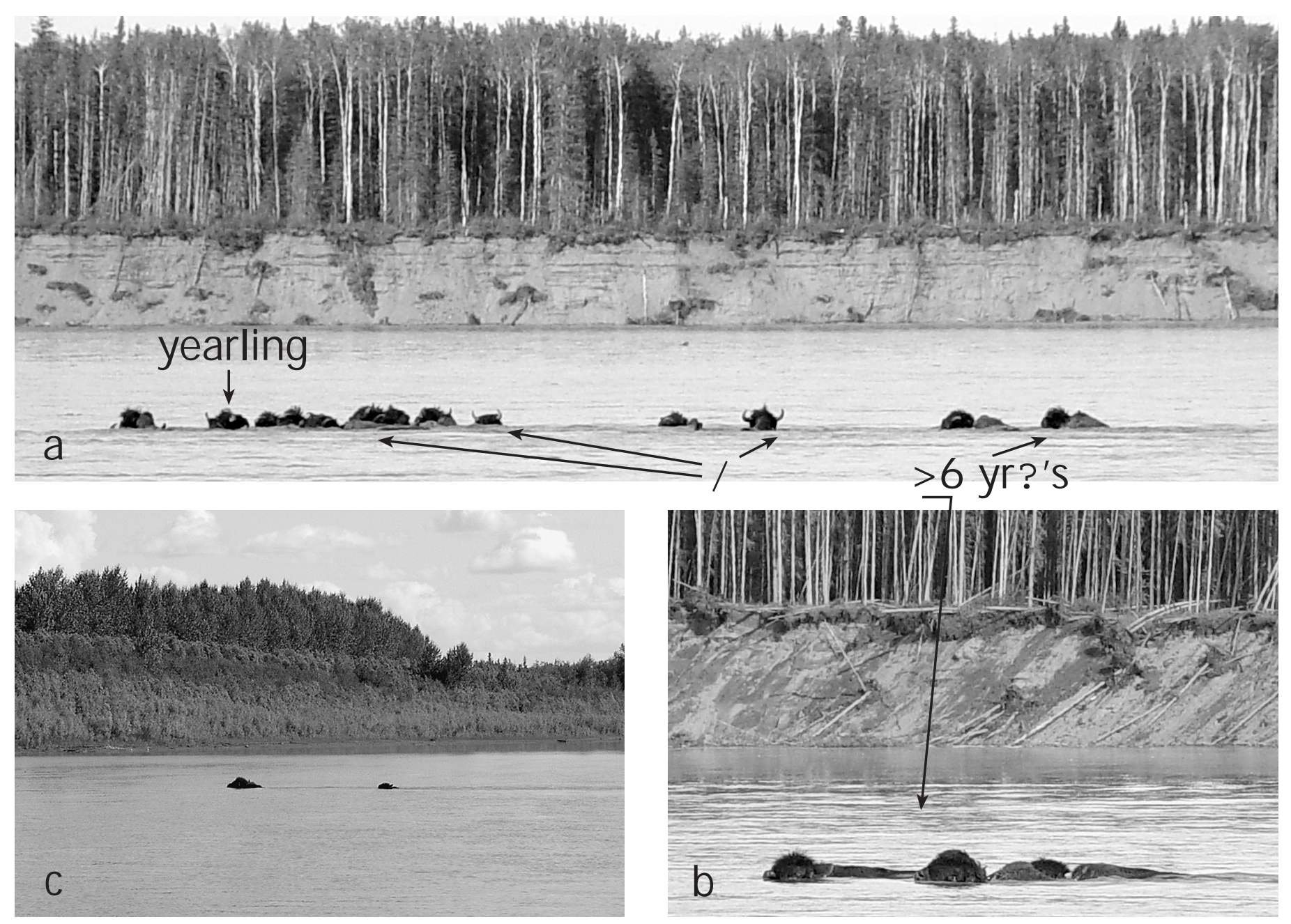

FIG 2. Bison swimming across the Liard River: (a) majority of the group observed in 2002 dominated by females (/ ) and yearlings; (b) lagging mature males (? ) of the group observed in 2002; and (c) a female and a calf observed as they negotiated a secondary channel in 2003.

Currently, the Nahanni wood bison population has established itself along both sides of the Liard River Valley from the Blackstone River southward to northern British Columbia, and it numbers ca. 200 individuals (Fig. 1).

During summer, Nahanni bison often use riparian areas and gravel/sand bars along the Liard River (J. Nishi and T. Ellsworth, pers. obs.; Leon Konisenta, pers. comm. July 2002), presumably because those areas provide relief from insects and access to high-quality forage, consisting of new growth of sedges (Carex spp.) and willows (Salix spp.). In summer, local residents of Fort Liard and Nahanni Butte use the Liard River for transportation and often see bison swimming across the river. Residents of Nahanni Butte report two places in particular where bison cross the Liard River: an area near Swan Point, east of Nahanni Butte, and an area near Netla, south of Nahanni Butte (Leon Konisenta, pers. comm. July 2002; Fig. 1). Residents of Fort Liard report that bison cross the Liard River just north of the confluence of the Muskeg and Liard Rivers and north of the confluence of the Kotaneelee and Liard Rivers (Dale Timbre and Jimmy Deneron, pers. comm. July 2002; Fig. 1).
The ability of bison to swim successfully across the Liard River is important in the ecology of this population: open-water crossings allow bison to access forage in riparian habitats throughout the river valley. The detailed reporting of such an event is especially important given recent proposals for seismic testing down the Liard and Mackenzie Rivers. In this note, we describe observations of wood bison groups swimming across the Liard River near Swan Point in July 2002 and near the Muskeg River in July 2003. Our observations were made opportunistically while we were conducting sex and age classification surveys of bison by boat along the Liard River from the Northwest Territories-British Columbia border north to the Blackstone River.

\section{DESCRIPTION OF OBSERVATIONS}

At 1916 h on 16 July 2002, we observed a group of 18 wood bison in the Liard River approximately $600 \mathrm{~m}$ east of a small snye on the eastern shore $\left(61^{\circ} 4^{\prime} \mathrm{N}, 123^{\circ} 9^{\prime} \mathrm{W}\right)$. We immediately stopped our boat motor and drifted down- 
stream while continuously observing the group of bison for almost 30 minutes, until all the animals in the group had reached the opposite shore and wandered in amongst the dense riparian willow growth. With a hand-held global positioning system, we recorded river current speed $(14-16 \mathrm{~km} / \mathrm{h})$, approximate route and estimated distance (3.6 km), and total duration (ca. 27 minutes) of the bison's swim from the east shore to the west shore. We used binoculars $(7 \times 35)$ and a digital camera with a $10 \times$ precision digital zoom lens to classify all animals into discrete sex and age classes (Komers, 1992) and document their body positions in the water while swimming (Fig. 2). The group consisted of three yearlings, 11 females ( $\geq 2$ years old), and four mature adult males ( $\geq 6$ years old). When our observations began at $1916 \mathrm{~h}$, the lead animals were approximately $600 \mathrm{~m}$ from the eastern shore where they had entered the river. The last animal ended its swim at $1938 \mathrm{~h}, 22$ minutes later. We conservatively estimated that the animals took no less than 27 minutes to swim across the river.

At $1637 \mathrm{~h}$ on 15 July 2003, three authors (N. Larter, T. Ellsworth, and D.G. Allaire) observed two females ( $\geq 2$ years old) and three calves of the year swimming across a secondary channel of the Liard River amongst the islands $15 \mathrm{~km}$ north of Fort Liard $\left(60^{\circ} 22^{\prime} \mathrm{N}, 123^{\circ} 24^{\prime} \mathrm{W}\right)$. The $200 \mathrm{~m}$ span the animals swam had a current speed of 4-6 km/h, and it took the calves about three minutes to negotiate it. Like the mature males, the calves of the year managed to keep only their heads above water when swimming (Fig. 2).

\section{DISCUSSION}

The Liard River is a major drainage that cuts through the current range of occupancy of the Nahanni wood bison population. During winter, the river is frozen and presents no barrier to bison movements. Similarly, in summer, even when water levels are high, flow rates average ca. 4000 $5000 \mathrm{~m}^{3} / \mathrm{s}$ (Randy Wedel, pers. comm. January 2003), and river currents are $14-16 \mathrm{~km} / \mathrm{h}$, the Liard River apparently does not present a physical barrier to bison movements. In addition to our observation, others have been recorded. Local residents traveling the river from Nahanni Butte north to Blackstone often observe bison swimming across the river throughout the summer months (Leon Konisenta, pers. comm. July 2002), and tourists canoeing this stretch of river have also observed bison swimming across the river (Ann Johnson, pers. comm. July 1991). According to residents of Fort Liard, bison are consistently seen swimming across the Liard River near the Muskeg or Kotaneelee tributaries, but only in September (Jimmy Deneron, pers. comm. July 2002). Whether or not the basis for movements across the river is the same in these two distinct parts of the range is unknown. One common underlying feature of the areas where bison cross the river is that at least one shoreline has extensive sand or gravel bars, or both.
Drowning is a source of mortality for other bison populations such as those in Wood Buffalo National Park, Yellowstone National Park, and Mackenzie (Meagher, 1973; Carbyn et al., 1993; Damien Joly, pers. comm. May 2003). Although accidents are not usually considered as a substantial mortality factor, bison population dynamics are often punctuated by mass "accidental deaths" when entire groups of animals are lost (Meagher, 1973). Before the damming of the Peace River, major spring drownings of Wood Buffalo Park bison were not uncommon; 3000 animals were lost in one year (Fuller, 1966; Carbyn et al., 1993). In the Mackenzie Bison Sanctuary, 172 animals died after breaking through the spring ice of a large, shallow lake. The distribution of these animals indicated not a mass drowning of one group, but a number of different group drownings along the lake edge. However, the total number of animals lost in spring 1989 was ca. $10 \%$ of the total population at that time. During both fall freeze-up and spring breakup periods, animals negotiating water bodies can break through or become stranded because of dangerous ice conditions. Drowning mortalities for the Nahanni population are generally reported around spring breakup, when the levels of water and ice fluctuate substantially and rapidly. Animals caught along the river banks and on the riverine islands during this time are susceptible to being swept away and to drowning. Only one or two drownings of individual animals are reported annually for the Nahanni population; no drownings of bison groups have been reported.

During the ice-free season, local river travelers are aware that they may encounter swimming bison, and they avoid disturbing them. Groups of swimming bison are particularly susceptible to disturbance. The group may disperse, some animals trying to return to where they entered the river while others continue their crossing. In large rivers with strong currents, a small shift in the crossing direction could substantially increase the crossing distance and time required to make the crossing.

Large males may be especially susceptible to disturbance. The large body mass of mature males causes them to sit low in the water. Unlike the adult females and yearlings, which were able to carry their entire heads above the water, the mature males were able to keep only their nostrils and the tops of their snout above water (Fig. 2), and they took several minutes longer to negotiate the crossing. There are reports of bison being drowned as a result of being swamped by waves when swimming across large lakes (see Carbyn et al., 1993).

We think that calves are more susceptible to hypothermia than other sex/age classes of bison because of their high surface-to-volume ratio. Although we did not observe any calves of the year swimming across the river during high-water conditions, when current speed was $14-16 \mathrm{~km} / \mathrm{h}$, we suggest that calves would be the least able to tolerate direct disturbance that might prolong their swimming time during river crossings. We believe that calves can negotiate such water conditions because on the 
morning of 17 July 2002, we observed 34 bison, including two calves, within metres of where the group of 18 animals had completed their crossing the previous evening. Our observations of calves swimming in slower-moving secondary channels (with current of $4-6 \mathrm{~km} / \mathrm{hr}$ ) indicate that calves, like adult males, sit low in the water column and may be susceptible to being swamped by waves.

Increased vehicular traffic on the Liard River, associated with resource development, increases the potential for interactions with and disturbance of swimming bison. Both direct disturbances (like collisions) and indirect disturbances (like increased waves and wakes or altered crossing routes) have the potential to increase drowning mortalities. Any increase in mortalities could impact the Nahanni population, which numbers only a few hundred individuals. The potential for interactions with swimming bison must be understood and considered in future proposals for seismic exploration of the Liard River. To reduce disturbances from these interactions, vehicular traffic encountering swimming bison should be slowed and stopped until the animals have reached the shoreline.

\section{ACKNOWLEDGEMENTS}

We thank Leon Konisenta, Chief of the Nahanni Butte Dene Band, for taking the time to share his observations and knowledge of wood bison in the area. Randy Wedel, Water Survey of Canada,
Yellowknife, generously provided water flow data for the Liard River. Robert Mulders provided the digital camera. Funding for the research was provided by the Department of Resources, Wildlife \& Economic Development. Bill Fuller, Damian Joly, and one anonymous reviewer provided helpful comments on earlier drafts of this manuscript.

\section{REFERENCES}

CARBYN, L.N., OOSENBRUG, S.M., and ANIONS, D.W. 1993. Wolves, bison and the dynamics related to the Peace-Athabasca Delta in Canada's Wood Buffalo National Park. Circumpolar Research Series No. 4. Edmonton: Canadian Circumpolar Institute, University of Alberta. $270 \mathrm{p}$.

FULLER, W.A. 1966. The biology and management of bison of Wood Buffalo National Park. Wildlife Management Bulletin Series $1.52 \mathrm{p}$.

GATES, C.C., STEPHENSON, R.O., REYNOLDS, H.W., VAN ZYLL DE JONG, C.G., SCHWANTJE, H., HOEFS, M., NISHI, J., COOL, N., CHISHOLM, J., and KOONZ, B. 2001. National recovery plan for the wood bison (Bison bison athabascae). National Recovery Plan No. 21. Ottawa: Recovery of Nationally Endangered Wildlife (RENEW).

KOMERS, P.E. 1992. Mating strategies of male wood bison. Dissertation, Department of Biology, University of Saskatchewan, Saskatoon, Saskatchewan. 149 p.

MEAGHER, M.M. 1973. The bison of Yellowstone National Park. National Parks Service Scientific Monograph Series No. 1. 